\title{
Correspondence
}

To the Editors:

\section{Birth of immunisation (Based on the observations of a nature lover)}

Sri Lanka Journal of Child Health, 2004; 33: 60

The sun drove off the twilight gray And promised all a cloudless day His yellow beams danced o'er the dews And changed to gems their pearly hues

The song-birds met on every spray And sung as if they knew the day The blackbird piped his mellow note The goldfinch strained his downy throat

To join the music of the plain The lark poured down no common strain The little wren, too, left her nest

And striving sang her very best

The robin wisely kept away His song too plaintive for the day 'Twas Berkely Fair, and Nature's smile Spread joy around for many a mile

The rosy milkmaid quits her pail The thresher now puts by his flail; His fleecy charge and hazel crook By the rude shepherd are forsook;

The woodman too, the date to keep Leaves Echo undisturbed in sleep; Labour is o'er - his ragged chain Lies resting on the grassy plain ${ }^{1}$.
The writer was obviously a great lover of nature with acute powers of observation. It is said that as a boy he could name every plant by the roadside and recognize the cry of every bird. These lines were written by Edward Jenner (1749-1823).

It is his love of nature that made him abhor sickness that deformed beauty. To him scars were sacrileges. Steeped in the countryside surrounded by farmlands, he noticed that milkmaids had smooth unscarred faces. The country-belief that "infection with cow pox prevented small pox" triggered in him a discovery of far reaching importance.

Long years of research by the writer of these lines culminated in mankind eradicating a once rampant communicable disease and controlling many more childhood infectious diseases.

P.S. The last paper read by Edward Jenner at the Royal Society (of which he was a Fellow).was on "Migration of Birds".

\section{References}

1. Canning J. 100 Great Lives. 3rd ed. New Delhi, Rupa \& Co. 1988.

Manouri P Senanayake

Professor and Head, Department of

Paediatrics, University of Colombo 